\title{
"The Root of All Evil is Inactivity": The Response of French Psychiatrists to New Approaches to Patient Work and Occupation, 1918-1939
}

\author{
Jane Freebody
}

\section{INTRODUCTION}

This chapter focuses on the varied responses of French psychiatrists to new theories of patient occupation emerging after World War I (1914-18). The voices that come across in this chapter are those of psychiatrists; the psychiatrists who criticised the way work and occupation were organised and who advocated the adoption of the new ideas in French asylums, and those who chose to ignore them. It is argued that the voices of the psychiatrists in favour of the new methods were "drowned out" by competing pressures, such as the desire of French psychiatrists to be

This research was funded by the Wellcome Trust (Grant No. 108615/Z/15/Z).

\footnotetext{
J. Freebody $(\square)$

Oxford Brookes University, Oxford, UK

e-mail: jfreebody@brookes.ac.uk

(C) The Author(s), under exclusive license to Springer Nature

Switzerland AG 2021

R. Ellis et al. (eds.), Voices in the History of Madness, Mental Health in Historical Perspective,

https://doi.org/10.1007/978-3-030-69559-0_4
} 
regarded as "scientific", financial expediency and staff resources. The voices of the patients are not heard in this study. Without access to patients' medical records, to which letters, poems, journals and other personal accounts were sometimes appended, it is difficult to gauge what the patients themselves felt about the activities in which they were expected to participate. There is an assumption that patients preferred to be occupied, rather than left with nothing to do, but the evidence does not suggest that they were consulted. The asylum records studied (the annual reports made by the psychiatrists in charge of patient care within the asylums to the local Prefecture) give us an idea of the daily routines, the living conditions, food and the variety of treatments, including work, that comprised the patient experience, but the patients' opinions on these matters are not recorded. In fact, one of the striking impressions of one French psychiatrist, on witnessing the new methods of occupation in practice, was the silence observed whilst patients were working, suggesting that patients' voices were not meant to be heard.

Patients had been given work to do since the advent of asylums in the early nineteenth century. The work comprised helping in the kitchens, laundry and workshops, labouring on the farm or in the grounds and performing household chores such as cleaning and polishing. This work was originally perceived as therapeutic by the early nineteenth-century moral therapists, but as the century wore on, the benefits of patient work to the institution began to take priority over its benefits to patients. The new theories regarding the occupation of patients emerging in the early twentieth century re-emphasised the therapeutic properties of work and recreational activities and required intensive input from asylum staff. While these new ideas were greeted very positively by some, most French psychiatrists did not put them into practice. Patient work failed to evolve significantly during the interwar period in France, remaining similar in character to the decade before 1914. The chapter examines the ideological, organisational, social and economic factors that contributed to a lack of support for the new theories by psychiatrists working in asylums, specifically the Asile Clinique in Paris, the most prestigious of the Seine department's six asylums, and the Asile de la Sarthe in Le Mans, a town 185 kilometres south-east of Paris, in the rural department of La Sarthe.

One of the most significant contributory factors was ideological and related to the way French psychiatrists interpreted the causation of mental disorder. Since the late eighteenth century, psychiatry has been characterised by competing explanatory theories regarding the origin of mental disorder, one emphasising psychosocial factors that portrayed insanity as 
an illness of the mind or spirit brought on by external factors such as personal circumstances, emotional issues or family matters, and the other indicating an organic, or physiological cause that located the origin of mental symptoms in the brain or central nervous system. ${ }^{1}$ In the early twentieth century, most French psychiatrists were "organicists", that is, they interpreted mental disorder physiologically, or as "matter", as Pradipto Roy argues in Chap. 3. This perspective discouraged the use of psychological treatments, such as occupational therapy. Other factors contributing to a failure to adopt the new methods included the internal management structure of French asylums; economic pressures following World War I and the need to keep asylum running costs down; the poor quality and inadequate quantity of French mental nurses and other support staff; and overcrowding (which made the delivery of any treatments difficult). These impediments meant that new methods of occupational therapy were only introduced to French psychiatric hospitals (as asylums were renamed in 1937) after World War II.

\section{HisTORIOGRAPHY}

Patient work is often described in studies focusing on individual asylums or on moral treatment, but has rarely been assessed in its own right, despite its centrality to the daily asylum regime. There are notable exceptions, including an edited volume by Waltraud Ernst (2016), and studies by Véronique Fau-Vincenti (2014), J-P. Arveiller and Clément Bonnet (1991); Jennifer Laws (2011); Vicky Long (2013, 2006); Geoffrey Reaume (2006); and Jean-Pierre Goubert and Rémi Remondière (2004). ${ }^{2}$ Ernst's edited volume constitutes the first attempt to analyse patient work in a range of psychiatric institutions, but to date, little has been written on patient work in interwar France.

\section{Patient Work Before 1918}

Work formed an essential aspect of moral therapy, which emerged in the context of the humanitarian ideology of the Enlightenment during the late eighteenth century. Moral therapy was a psychological method of treatment aimed at developing a patient's ability to control his/her symptoms. Philippe Pinel (1745-1826), the French pioneer of moral therapy, advocated a balanced regime of work, recreation and rest for patients in his Traité of 1800. The next generation of French psychiatrists, including 
Jean-Étienne Dominique Esquirol (1772-1840), Maximien Parchappe (1800-1866) and Jean-Pierre Falret (1794-1870), continued to advocate moral therapy and extol the virtues of therapeutic work. French psychiatrists' commitment to patient work was indicated by the fact that France was the only country in Europe where legislation (introduced in 1838 and amended by the Ministerial Circular No. 7, dated 20/3/1857) ensured its provision for patients. The 1857 circular emphasised the therapeutic importance of patient work and the role of the doctor in prescribing it. Article 150 stated that "Work is instituted in the establishment as a means of treatment and distraction for patients", while Article 154 declared that "The chief medical officer (le médecin en chef) alone decides which patients should work and the type of work they are able to do". ${ }^{3}$

Support for moral therapy waned by the mid-nineteenth century, as an organicist interpretation of mental disorder, based on the theory of hereditary degeneration proposed by Bénédict-Augustin Morel (1809-73) in 1857 gained popularity. Morel's theory, that a neuropathic (i.e. physiological) predisposition to mental disorder was transmitted through heredity, soon dominated interpretations of mental illness by psychiatrists in France and elsewhere on the Continent. ${ }^{4}$ Degeneration theory remained influential in Denmark, for example, until the 1940s, as Jennie Sehr Junghans observes in Chap. 5. Morel's theory of hereditary degeneration provided psychiatry with a "convincing biological explanation"-in the absence of any other-about how mental disease was acquired. ${ }^{5}$ It also helped explain the accumulation of incurable cases that were causing overcrowding in most French asylums, rendering impossible the delivery of effective moral therapy. The therapeutic pessimism surrounding degeneration theory, which contradicted the views of the moral therapists, led to a concept of the asylum as a custodial institution, where patients were routinely managed rather than cured. Patient work continued to be part of the daily regime for patients, independent of its original context. By the early twentieth century, when most public asylums were overcrowded and underfunded, particularly those in Paris, patient work became increasingly geared towards institutional profit. "Idleness" was not tolerated amongst the pauper class of patients who were expected to contribute to the costs of their care, according to the legislation of 1857 . This insistence on "usefulness" is echoed in Iain Hutchison's chapter on the Scottish Institution for the Education of Imbecile Children where the more capable inmates were expected to do some form of work. 


\section{The Aftermath of World War I}

The French economy was shattered by World War I. France had lost 7.2\% of its human capital, $25 \%$ of its domestic assets and $49 \%$ of its overseas assets as a result of the conflict; $31 \%$ of its GDP was spent on the war effort. ${ }^{6}$ The destruction caused by the war was evaluated at 34 billion Francs by the Reparation Committee. ${ }^{7}$ Government finances were therefore extremely stretched. Meanwhile, the asylum system was in disarray following the disruption caused by the war. Two particularly vociferous psychiatrists from the French Asylums' Medical Society (la Société Médicale des Asiles), namely Édouard Toulouse and Henri Colin of the Villejuif Asylum, described the post-war state of the Seine asylums as "deplorable". They were unhygienic and overcrowded; they lacked outdoor space and adequate laboratories. Distractions (including occupation), considered so important for patients whose conditions were beginning to improve, were practically non-existent. ${ }^{8}$ Treatment for curable patients was compromised by mixing curable and incurable patients in the same quarters, while the ratio of 400 patients per doctor prevented the application of any effective treatment for more than a few patients. ${ }^{9}$ Most asylums lacked the equipment necessary for delivering modern treatments, such as hydrotherapy, UV-ray treatment, electrotherapy and radiography. Many patients, who, in more favourable conditions, might be cured or improved, remained in asylums far longer than was necessary. Toulouse and Colin maintained that services for the mentally ill were "a long way from the peak of psychiatric science" and that the paucity of equipment and facilities was an embarrassment when doctors visited from abroad. ${ }^{10}$ Various reforms were put forward, at the heart of which was the provision of separate facilities for the care of incurable and curable cases. It was understood that the reforms would be costly; it was therefore suggested that the economic value of patient work be enhanced. ${ }^{11}$

\section{Criticisms of Patient Work}

A focus on the financial benefits of patient work led to criticism from certain psychiatrists who believed that patient work was not being used to its full therapentic potential. Julien Raynier (1888-1936) ${ }^{12}$ and Henri Beaudouin (1885-1968), ${ }^{13}$ whose publication L'Aliéné et les Asiles d'Aliénés au point de vue administrative et juridique (1924, 1930) became known as the "bible" for asylum doctors, maintained that patient work 
was neglected or poorly organised in many asylums. ${ }^{14}$ Work, the authors reminded doctors, had been accepted as beneficial to a patient's mental and physical well-being since the early nineteenth century. Among the benefits, a patient gained "social dignity" through productive work, even if minimal results were achievable..$^{15}$ Work accelerated convalescence from acute psychosis and provided an excellent treatment for chronic patients. Farm work (which also provided the asylum with nutritious, fresh food) was considered particularly effective. However, the purpose of the work was therapy, and patients should not be expected to be as productive as "normal" individuals. It was essential that the personnel directing patient work understood this and treated patients appropriately. ${ }^{16}$

Psychiatrists Charles Ladame ${ }^{17}$ and Georges Demay ${ }^{18}$ tried to advance contemporary thinking on patient work in their work, La thérapeutique des maladies mentales par le travail published in $1926 .{ }^{19}$ They highlighted that in the past, patient work had been indicated for convalescent and calm, chronic patients, but not for patients at the acute stage of their illness, nor for those suffering from severe mania or melancholia. They suggested that medical thinking on this matter had evolved and that work could be appropriate for acute patients, although not at the very beginning of their illness, when bed-rest was indicated. They believed, for example, that it was not considered necessary to wait until the agitation of delirious patients had completely disappeared. Work could fix their attention, channel their energy and facilitate a change in habits. ${ }^{20}$ The benefit of work as a distraction was illustrated by the case of a patient suffering from delusions of persecution who remained perfectly calm when working in the fields for six days out of seven, but on Sundays (when patients did not work) his delirium returned, resulting in noisy monologues and gesticulations. ${ }^{21}$ Work was considered beneficial for melancholic patients, either as a means of encouragement to engage with their surroundings, or as a refuge and a distraction. In Ladame and Demay's opinion, some patients suffering from dementia ${ }^{22}$ were also capable of work, including those suffering from dementia praecox. ${ }^{23}$ They noted that BénédictAugustin Morel found work helped to retard the deterioration of dementia praecox patients, while Eugen Bleuler (1857-1939) claimed that work was one of the most effective means of treating schizophrenia. ${ }^{24}$

Patients at the acute phase of their illness were required by chief medical officers to remain under medical surveillance. If acute-stage patients were to be given work, workshops had to be situated within the interior of the patient quarters. This was most unusual in French asylums; an enquiry 
had revealed that only two out of the 25 French asylums surveyed had interior workshops. ${ }^{25}$ Most of the work available for patients took place in the asylum workshops situated in the maintenance areas away from the wards, or in the kitchens, laundry or grounds for cultivation. Establishing interior workshops was recommended by Ladame and Demay since they could provide work (such as basketry, mat-making, brush-making, bookbinding, knitting or sewing) for a large group of patients who would otherwise be left unoccupied. The authors suggested the introduction of local industries, such as lace-making, glove-making or weaving, with which patients may have been familiar. They cited the example of the Third Section of the Villejuif Asylum in Paris, where even the most "difficult" patients worked in small workshops in the interior of their quarters. ${ }^{26}$

The Villejuif Asylum's Third Section for criminal and dangerous patients, established by Henri Colin in 1910, was one of the few French asylums where interior workshops existed, and could provide a model for other establishments. Whilst the primary purpose of work for these criminal patients was to ensure that they contributed to the costs of their care, as they would have been expected to do in prison, it was clear that the work also had a beneficial effect on their behaviour. ${ }^{27}$ Colin, who had outlined the work of the Third Section in the journal Annales Médicopsychologique in 1912 and 1913, claimed that although doctors had not sent agitated or violent patients to the workshops in the past because they required continual surveillance, many of these patients were excellent workers. ${ }^{28}$ By situating the workshops (including shoe-repair, machineknitting, tailoring, furniture repair and carpentry workshops) within the patient quarters, productive work could be achieved, supervised by nurses experienced in manual labour. ${ }^{29}$ An economic benefit for the institution could therefore be derived from patients whose labour had not previously been "exploited" at the same time as improving behaviour.

As Dr Calmels highlighted in a paper presented to the congress of French alienists and neurologists in Geneva in 1926, in which he outlined the work regime of the Villejuif's Third Section, interior workshops would enable the employment, not only of the criminally insane or of potentially dangerous patients, but of many other hitherto unoccupied patients. Patients suffering from chronic delirium, ${ }^{30}$ dementia praecox or general paralysis of the insane (chronic mental disorder associated with late-stage syphilis), for example, who were forced to remain in their quarters with nothing to do, despite being capable of simple work, could be employed. ${ }^{31}$ The atmosphere of boredom and sadness, so often evident in quarters 
where patients were idle, could be replaced by one of activity and purpose. Furthermore, claimed Calmels, chronic patients could fulfil a useful, social role. ${ }^{32}$ Calmels was advocating the provision of work for these patients on the grounds of both humanity and economy; on the one hand relieving the boredom of patients unable to leave the ward, and on the other hand, enabling the institution to benefit from another source of labour.

Ladame, Demay and Calmels were clearly advocating that work should be provided for a wider cohort of patients, with a more diverse range of conditions, than had previously been considered beneficial from a medical perspective. The average percentage of patients given work in French asylums was not given in Ladame and Demay's 1926 report, but Dr Lautier quoted a figure of $50-55 \%$ in $1929 .{ }^{33}$ Demay maintained in an article in L'Hygiene Mentale in 1929 that the figures regarding patient workers in Swiss and Dutch asylums were "unknown in France". ${ }^{34}$ In the Swiss asylum at Wil, under Dr Schiller, $83 \%$ of male and $75 \%$ of female patients were working, while at the Santpoort asylum in Holland, 90\% of patients worked. ${ }^{35}$ Demay suggested that French doctors were being "too timid" in their allocation of work to patients. The peaceful, chronic patients and the inoffensive, intellectually impaired, together with the convalescents, were sent to work, but most of the other patients were consigned to overcrowded quarters and remained unoccupied all day, apart from a small number cleaning the wards. Demay said that it was time to get the agitated, the impulsive, the perverse, the violent and the escapees to work, by making the appropriate arrangements, such as introducing interior workshops and ensuring that adequate security measures were in place. ${ }^{36} \mathrm{He}$ believed that it was possible to occupy most patients in some sort of work. "The acute phase of psychosis should not present an obstacle" to work and the only contra-indications were "senility, physical weakness or illness" according to Demay. ${ }^{37}$

\section{"More Active Therapy"-A New Theory Regarding Patient Occupation}

Demay's ambitions to occupy more patients were encapsulated by the new method of "more active therapy" (MAT), developed in Germany by $\mathrm{Dr}$ Hermann Simon (1867-1947), director of the Gutersloh Asylum in Westphalia. Simon, writing in 1929, maintained that "idleness" was not only the "root of all evil ... but also of impending idiocy". ${ }^{38}$ He claimed 
that "powers that are not used diminish" and that "inactive loafing around breeds bad moods, moroseness, irritability" and brought patients into conflict with one another. ${ }^{39}$ His new approach, which he described as a method of "psychotherapy", involved the re-education of the patient through the establishment of a regular routine of occupation, rest and recreation. Although the therapeutic value of occupation was paramount, patient work had to serve a useful purpose as this was an important aspect of the re-education process. Patients needed to feel that their work was real and serious, only then would they take an interest in it. Simon insisted that a patient be pushed to "the upper limits of their abilities" as this was the only way to make progress. Identifying tasks of the appropriate level of complexity for each patient was "one of the most important as well as most difficult tasks for the psychiatrist". ${ }^{40}$ The first review of Simon's work appeared in France in L'Hygiène Mentale in $1929 .{ }^{41}$

French support for the German model might initially seem surprising since the French had been traditionally hostile to everything German since the defeat of France by Germany in the Franco-Prussian War of 1870-71. ${ }^{42}$ This defeat intensified the French sense of inferiority with regard to Germany, initiated by the loss of French scientific and medical supremacy to Germany earlier in the century. ${ }^{43}$ The university chair established in Germany in 1863 demonstrated German psychiatry's scholarly and scientific legitimacy, while the ground-breaking work of Emil Kraepelin (1856-1926), whose influential Textbook of Psychiatry was published in eight editions between 1883 and 1915, sealed their victory over French psychiatry. ${ }^{44}$ Postgraduate students flocked to Kraepelin's clinic in Munich, rather than Paris, to study psychiatry under the "new master" ${ }^{45}$ French psychiatrists were anxious to re-establish their reputation by emulating, or surpassing, German achievements. Recommendation of MAT may have been part of a conscious or unconscious attempt to ensure that French asylums kept pace with developments in Germany.

Simon's ideas were enthusiastically communicated to a French audience by psychiatrists Paul Courbon and A. Porot, following a visit to the Dutch asylum at Santpoort where his methods had been put into practice in 1926. Courbon and Porot shared their observations in the French journals Annales Médico-psychologique (1928) and L'Hygiène Mentale (1929). What so impressed Paul Courbon when he visited Santpoort in 1928 was the silence. Patients worked from 0900 to 1200 and from 1400 to 1700 and were not allowed to speak whilst working. ${ }^{46}$ The moment patients became agitated they were removed from the work room for half an hour 
to rest and then brought back again. If they re-offended, they were removed for a longer period; if this proved insufficient, the patients were given a sedative. Courbon found the results of this method were "extraordinary", while for Porot they were "revolutionary". ${ }^{47}$ The application of MAT totally transformed the atmosphere of asylums; everywhere there was silence, concentration and an impressive discipline. ${ }^{48}$ Porot believed that the methods he had witnessed at Santpoort and other Dutch asylums were not simply a way of filling the time and occupying idle hands, but an effective means of therapy that countered agitation and other symptoms. It was, as Courbon claimed, "une véritable rééducation". ${ }^{49}$ This enforced silence was reminiscent of moral therapy and its attempts to induce selfcontrol (or la police intérieure as Pinel called it) amongst patients and to encourage them to behave like people who were regarded as sane.

Simon elaborated his views in an article in the French journal L'Hygiène Mentale in 1933, explaining that "all psychotherapy is above all an education ... it acts on the will of patients with the goal of improving their ability to adapt to their environment". ${ }^{50}$ Patients lacked judgement and understanding, so doctors and nurses assumed the role of "spiritual guide", rather like that of a mother using her authority to guide a child in the appropriate direction. ${ }^{51}$ Simon maintained that authority was the basis of all successful psychotherapy; not force or strict rules, but the "spiritual superiority" of the therapist. This, he insisted, had been recognised by the great psychiatrists of the past such as Pinel, Reil, Griesinger and Conolly. ${ }^{52}$ It was important not to treat patients as "mad" but as sane individuals capable of "normal" behaviour. Patients were to be respectful of others, and to remain calm and orderly. They were not to use foul language or shout, to shred their clothes or march up and down. These objectives were best achieved by encouraging patients in an occupation, teaching them good working habits, and developing their sense of responsibility. ${ }^{53}$ Patients who behaved well and showed a willingness to work were rewarded with certain privileges such as greater freedom or attendance at special events (parties, concerts, theatrical performances). In contrast, those who engaged in antisocial behaviour were deprived of certain benefits. ${ }^{54}$ As a patient improved, $\mathrm{s} /$ he would be given work involving greater responsibility. It was important to keep raising the patient's expectations of him/herself to maintain progress. ${ }^{55}$ Outside working hours, the patient's mind should still be kept occupied with lectures, conversation and physical exercise. Patients should not be allowed to discuss or dwell upon their troubles; work and activities should distract them. ${ }^{56}$ 
Patients were thus expected to maintain certain standards of "normal" behaviour, based on contemporary perceptions of what that comprised. They were effectively being silenced by the asylum staff whose duty it was to enforce the "no talking" rule and to act as mentors to the patients, setting an example of hard work and self-discipline. Compliance was encouraged through a system of rewards and non-compliance resulted in expulsion from the working environment and periods of sedation. Although there was no evidence of restraint or punishment, signs of agitation or attempts by patients to discuss their concerns were clearly met with disapproval. Everyone was expected to perform some sort of work. Simon maintained that although work could not cure physiological conditions, such as brain disease, it could nonetheless strengthen a patient's physical and mental faculties. ${ }^{57} \mathrm{He}$ believed that every patient, even those at the acute stage of their illness, should be set to work on admission to hospital as this was one of the best means of combatting agitation, impulsivity and a tendency to violence. ${ }^{58}$

\section{The Effect of the New Theory on Practice IN Asylums}

The accounts written by French psychiatrists appearing in the professional journals between 1928 and 1936 regarding Simon's new approach to patient work indicate a considerable level of interest in developing the practice of therapeutic occupation for French asylum patients. However, the evidence does not indicate that the organisation of patient work changed significantly during this period. The percentages of patients who worked in the Asile Clinique and the Asile de la Sarthe did not increase. At the Asile Clinique, the percentage of patient workers fell from $28 \%$ to $20 \%$ between 1921 and 1926, although it increased to an average of $30 \%$ between 1927 and 1939 as a result of the drafting in of additional chronic patients. ${ }^{59}$ At the Asile de la Sarthe, the annual reports indicate that the percentage of patient workers fell slightly. In 1923, 59\% of male and 58\% of female pauper patients worked, and by 1937, these figures had fallen to $49 \%$ and $51 \%$ respectively. ${ }^{60}$ These figures are clearly well below those achieved at the asylums at Gutersloh and Santpoort (c. 90\%), and there is no indication that the chief medical officers adapted their daily regimes or their allocation of work to patients to accommodate those who were confined to their quarters. This might seem surprising given the absence of 
any other effective cures, at least at the start of the interwar period. ${ }^{61}$ Furthermore, the pressure on asylums to deliver "cured" patients back to the workforce, to aid the post-war reconstruction effort and to repopulate the factories which had lost so many young male workers during World War I, was intense, as General Councillor Louis Dausset reported in $1918 .{ }^{62}$ The new method was not only believed to be curative, but also fulfilled a rehabilitative function and was therefore allegedly helpful in returning recovered patients to work outside the asylum. There are a number of reasons, however, for an adherence to the status quo with regard to the prescription of patient work by French psychiatrists. These were related to the professionalisation of French psychiatry and mental nursing, and to the political and economic instability of the interwar years.

\section{IMPEDiments TO THE Adoption OF MORE ACTIVE Therapy}

\section{Professional Orientation of Asylum Psychiatrists}

As Porot highlighted in his 1929 article, the organicist stance of many French psychiatrists, who regarded mental disorder as a physiological, rather than a psychological, condition, presented a barrier to the replication of MAT in French asylums. ${ }^{63}$ Adherence to this organicist model of mental disorder allowed psychiatrists to demonstrate their scientific credibility and, as Jean-Christophe Coffin put it, "to be part of the flow of new knowledge stemming from biology and general pathology". ${ }^{64}$ This credibility was further enhanced by attempts to forge an alliance between psychiatry and the most prestigious of the medical disciplines in fin-de-siècle France, neurology. Neurologists, who specialised in diseases of the brain and the central nervous system, also took a physiological view of mental disorder and preferred biological over psychological methods of treatment. In a sense, psychiatrists were prevented from developing an independent voice by forging this alliance with neurology. The French, as Harry Paul observes, were especially proud of their scientific heritage, as the foundation of various scientific institutes (such as the Pasteur Institute, founded in 1888) during the nineteenth century, and state investment in scientific research during the early twentieth century attest. ${ }^{65}$ This pride helps to explain the emphasis within French medicine on scientific method and the keenness of French psychiatrists to be regarded as scientific. 
Patient work and occupation were not sufficiently scientific to enhance psychiatry's under-developed professional reputation.

A neurological approach to psychiatry was pursued at the Asile Clinique. It would be inaccurate to conclude that a neurological orientation precluded the prescription of work for patients as this was still deemed a useful means of distraction for chronically ill and incurable patients. However, neurologically oriented psychiatrists, with a preference for biological over psychological treatments, were less likely to be interested in the adoption of occupational therapy as a means of treating acute cases, since occupational therapy did nothing to enhance the scientific credentials of the psychiatrists. This is indicated by the small proportion of patients engaged in work at the Asile Clinique. This was also the case at the Asile de la Sarthe. The organicism and neurological approach of Dr Christy (chief medical officer 1935-39) was made explicit in his first annual report of 1935, in which he sought to impress upon the prefecture the "scientific trends" that guided his treatment methodology. ${ }^{66} \mathrm{He}$ divided patients into two categories, the intellectually impaired, who were incurable, and the mentally ill, who responded to treatment. The two categories, he maintained, required different therapeutic techniques. The intellectually impaired required treatment for any physical ailments; support; comfort; and the moral discipline provided by work. The mentally ill, on the other hand, required "aggressive biological treatment". ${ }^{67}$ The two types of treatment required different medical skill sets. When treating the intellectually impaired, the doctor had to be a psychologist, while the skills of a neuropsychiatrist were required to treat the mentally ill. This distinction had important implications for patient work. Christy made it clear in 1936 that he was more interested in neuro-psychiatry than psychological medicine. ${ }^{68}$ He wanted to focus on acute, curable patients, whom he would treat biologically. ${ }^{69}$ Christy's distinction between work for chronic patients and biological treatment for curable patients, and between the different skill sets required of doctors for each type of treatment (the first, psychological and the second, neuro-psychiatric) highlight the alignment between French psychiatry and neurology and suggest that Christy did not support the principle of treating acute patients with occupational therapy. It was not until the replacement of such a rigid physiological interpretation with a more environmental or social approach to mental disorder that occupation became recognised as an effective treatment. This was also the case in Denmark, as Junghans highlights. 


\section{Management Issues}

Had the chief medical officers of the Asile Clinique or the Asile de la Sarthe believed that the new methods of occupational therapy comprised an essential aspect of treatment (as many of their British colleagues did), they would have needed the authority to introduce them. As Simon emphasised, the successful introduction of MAT into asylums depended on control of the institution by a medical director, someone with the authority to ensure that all staff shared the same therapeutic ethos. Medical control of the work regime was essential to ensure that the work was oriented towards a therapeutic goal, rather than an economic one, a point emphasised by Seine asylum physician Jacques Vié in $1934 .^{70}$ The psychiatrist was the only person qualified to decide on the type of work to be allocated to each patient. At Simon's asylum in Gutersloh, Germany, the psychiatrists and senior nurses began each day dividing the work between patients and work teams, based on their knowledge of the patients, their conditions and their aptitudes. Each work team had a particular therapeutic goal which could be achieved by a certain type of work. Simon emphasised that these therapeutic goals might not always be in harmony with the interests of economic exploitation. Those responsible for asylum administration, claimed Vié, must be united in serving the best interests of patients, since any discord between the medical and economic teams could lead to severe difficulties and compromise the potential benefits of patient work. ${ }^{71}$ In France, although the legislation stated that work should be prescribed by the chief medical officer, overall responsibility for decisions regarding asylum management did not rest in the hands of a single medical director.

Unlike elsewhere on the continent, in France, responsibility for management of the asylum was shared between the chief medical officer and the asylum director, who controlled administrative and financial matters. The chief medical officers had autonomy in most medical matters, but patient work, which impacted on the financial management of the asylum, as well as being a means of therapy, was a contested area and a potential source of friction between the medical and administrative teams. As doctors Legrain and Demay wrote in their 1934 report (published in L'Aliéniste français in 1936), "it is clear that patient work is regarded differently by the economic and technical services and by the medical services". ${ }^{72}$ They observed that for the Administration, patient workers were divided into two groups, good workers and the rest, while for the medical 
team, productivity was not the main aim of the work. ${ }^{73}$ Compared with their Dutch colleagues, as Courbon and Porot observed, French doctors lacked the authority to insist upon a therapeutic objective for patient work. ${ }^{74}$ The voice of the French chief medical officer was effectively weakened by the management structure of French asylums. A medical director, as Demay maintained, invested with both medical and administrative authority, could balance the interests of patients and asylum management. ${ }^{75}$ Under the French asylum system, any proposed changes to the existing organisation of patient work that might compromise its contribution to the budget were likely to be rejected by the asylum director.

\section{Financial Issues}

The contribution made by patient work to asylum finances was particularly important following the economic devastation caused by World War I. By 1925, the social care budget of the Seine department was overstretched. In the light of the escalating costs of maintaining the Seine's mentally ill population, ${ }^{76}$ the General Council was seeking ways of reducing the paid asylum workforce of the Seine, so the work provided by patients was crucial. ${ }^{77}$ The General Council emphasised that using patient labour in the asylum workshops served to "lighten the maintenance costs which weighed so heavily on the collective purse" ${ }^{78}$ Concerns regarding the potential loss of the financial contribution made by patient work delayed the decision to transform the Asile Clinique from a general asylum serving a mix of curable and chronic patients, to one specialising in acute, curable patients. Work was not considered suitable for patients at the acute stage of their illness, according to the traditional view of patient work. By specialising in acute cases, the Asile Clinique risked losing its workforce of calm, chronic patients, who would be transferred to other asylums. A solution to the problem was eventually found in 1923 (although the project was not implemented until $1927 / 8$ ), involving the drafting in of 170 chronic patients ( 120 males and 50 females), accommodated in separate "workers' pavilions", to perform the duties required by the establishment workshops. ${ }^{79}$ These chronic patients brought the total number of patient workers to an average of 334 between 1929 and 1938, or c. 30\% of all patients.

Had the Asile Clinique employed the MAT method of occupation, a much higher percentage of patients would have been employed, since Simon maintained that patients at the acute stage of their illness could be given work. However, while the numbers of employed patients would 
have increased, much of the work performed would not have been productive. Furthermore, the acute patients would have required careful supervision, taking staff away from other duties. Paradoxically therefore, it was financially more expedient to remain with the existing system of allocating work to fewer patients (the chronic and convalescent patients) who were capable of productive work.

Productivity was carefully monitored at both the Asile Clinique and at the Asile de la Sarthe. At the Asile Clinique, the work carried out in each of the workshops, which collectively employed $25-40 \%$ of the patient workforce, was monitored carefully, and the number of days worked by patients in each was recorded. The value of the work provided by the patients was evaluated and appeared in the asylum accounts as the produit du travail des aliénés, while the value of produce harvested from the market gardens and farm (cultivated using patient labour) was recorded as the produits recoltés. Interestingly, it was the asylum director who reported on patient work in the asylum annual reports, emphasising its administrative function, rather than its therapeutic value. At the Asile de la Sarthe, for example, frequent references were made to the 'profits' generated by the asylum bakery and by agricultural exploitation in the asylum director's annual reports, which were separate from those produced by the chief medical officer. ${ }^{80}$ In 1920 , the asylum director commented that the farm had given good results that year, saving the asylum 38,718F. The products, including bacon, eggs, chicken, fruit and vegetables, were all consumed on the premises, thereby benefiting the establishment, as well as the patients involved in their production. ${ }^{81}$

\section{Staffing}

The adoption of MAT required the co-operation of all members of the asylum staff; in French asylums this was rendered problematic by the dual management structure indicated above. Staff training and numbers also presented impediments to the introduction of MAT. Although workshop managers were responsible for supervising the patient workers assigned to their workshops, they lacked training in how to manage and respond to mentally ill patients. Demay observed in 1929 that workshop managers appeared unaware of the nature of mental illness and many showed neither kindness nor patience towards the patients working in their workshops. ${ }^{82}$ Reporting to the asylum director, they were overly concerned with productivity and failed to prioritise the therapeutic, re-educative purpose of 
patient work. Patients were sometimes excluded from workshops for being disruptive, or too placid, or for showing a "lack of respect" for an employee. Demay recommended that each workshop manager should undergo a period of training in medical services. ${ }^{83}$ The existing relationship between workshop managers and the medical team was an impediment to the institution of MAT.

Highly trained nursing staff were also required for the successful introduction of MAT, since, as Legrain and Demay highlighted in their 1934 report, the application of therapeutic work rested with the nurses ${ }^{84}$ Nurses needed to have the skills to motivate patients, to direct the activity of distracted or confused patients, to intervene if a patient became agitated and to modify the work according to how a patient was coping. They needed to be familiar with their patients' conditions, interests and capabilities, and able to handle them with patience and tact. ${ }^{85}$ However, formal training in mental nursing was rare in France in the immediate aftermath of World War I. It was provided in some departments, including the Seine, where a mental nursing school had been established at Ste Anne's in 1882, but many departments, including La Sarthe, lacked a school. ${ }^{86}$ As a result, the skills of French mental nurses compared unfavourably with those of their Dutch colleagues. After visiting the Dutch asylum Santpoort in 1928, French psychiatrist Paul Courbon observed that Dutch nurses regarded the profession as a vocation, rather than just a job, and they were recruited from a more highly educated and cultivated class than in France. ${ }^{87}$ Nurses tended to be recruited from peasant or labouring stock and lacked a vocational calling to their profession. ${ }^{88}$ In 1935 , it was estimated that only $5 \%$ of the Seine's mental nurses held a certificate of primary education, and some were illiterate. ${ }^{89}$ These comments did not augur well for the ability of Asile Clinique nurses to take on the additional responsibilities associated with MAT.

At the Asile de la Sarthe, the quantity of nurses was just as much an issue as their quality. In 1920 the Asile de la Sarthe director reported that they had barely enough staff to give nurses a rest day every week. ${ }^{90}$ In 1933, the new chief medical officer, Dr Schutzenberger, highlighted that although "on paper" there might be an appropriate ratio of patients to nurses, in reality, the actual number of nurses was insufficient. ${ }^{91}$ Nurses were often required to be somewhere other than the patients' quarters (such as delivering patients to the workshops), and days off and holidays had to be taken into consideration..$^{92}$ Despite a salary rise in 1920 , few applicants were able to satisfy the asylum's requirements for nursing 
experience gained at other local hospitals or asylums. The introduction of the 40-hour week in 1937, requiring an increase in the number of male nurses from 46 to 125 , compelled the Asile de la Sarthe to recruit individuals with no experience of nursing. ${ }^{93}$ As a result, the chief medical officer Dr Christy, reported that he had been obliged to organise courses for all male nurses, including elementary instruction in anatomy, physiology and hygiene, since he could achieve little if his staff lacked any understanding of and had scant interest in their work. ${ }^{94}$ These nurses were unlikely to have the time, knowledge or inclination to adapt to new, more intensive methods of patient occupation.

The Asile de la Sarthe also experienced difficulty recruiting junior medical staff. Until the mid-1930s, the chief medical officer had been the only medically qualified member of staff. Dr Schutzenberger highlighted that it was impossible for a single doctor to treat $c .850$ patients without either a medical assistant or interns. ${ }^{95}$ Le Mans was a small town without a university (at that time), which made the recruitment of interns difficult. Christy concluded that without interns, he could not offer his preferred modern treatments, particularly as he was also running courses for the male nursing staff. ${ }^{96}$ Given the level of involvement expected of medical staff in the application of MAT, the prospect of its introduction at the Asile de la Sarthe was remote.

\section{CONCLUSION}

This chapter has argued that the voice of the French psychiatrists who advocated a new approach to patient occupation during the interwar period failed to be heard by the chief medical officers of asylums. This was in part to do with an adherence to an organicist interpretation of mental disorder by doctors who were anxious to augment their professional credentials by moving more closely towards mainstream medicine, specifically neurology. This approach, which favoured biological means of treating acute cases, was at odds with the psychotherapeutic method of MAT. Patient work continued to be considered beneficial for convalescent, incurable and chronic patients, as it had been since the nineteenth century, but biological treatments were prioritised for acute patients. Furthermore, any change to the status quo in terms of the supply of patient labour could have compromised its economic contribution to institutional running costs. This would have generated problems for asylum directors who were tasked with managing asylum budgets, which were particularly tight 
during the challenging financial climate in the aftermath of World War I and the Great Depression of the early 1930s. Chief medical officers were not in a position of sufficient authority to insist upon a wholly therapeutic rationale for patient work. Even if they had had this authority, issues related to staff quality and quantity, together with overcrowding and poor facilities, would have posed difficulties for the introduction of MAT. Inadequate training and low levels of educational attainment, coupled with a lack of commitment to caring for the mentally ill, meant that French mental nurses were ill-equipped to deliver MAT. Doctors were too few in number to devote sufficient time to the method. Workshop managers in the asylum service departments were too focused on productivity and a lack of space, due to overcrowding, precluded the installation of interior workshops. Together, these factors served to quash the voices of psychiatrists seeking to reform the organisation of patient work in French asylums. The patients' views about how they were occupied failed to come across. Reform of the asylum system begun tentatively just before the outbreak of World War II, and gathering pace after Liberation in 1945, eventually led to the introduction of occupational therapy in the 1950s.

\section{Notes}

1. Mark S. Micale, "The Psychiatric Body", in Companion to Medicine in the Twentieth Century, ed. Roger Cooter and John Pickstone (London: Routledge, 2000), 323-346, 323.

2. Waltraud Ernst, ed., Work, Psychiatry and Society, c.1750-2015 (Manchester: Manchester University Press, 2016); Véronique Fau-Vincente, "Valeur du Travail au Troisième Section de l'Hôpital de Villejuif: Entre thérapie et instrument de discipline", Savoirs, Politiques et Pratiques de l'exécution des peines en France an XXe siècle (2014). http://criminocorpus.revues. org/2788. Accessed 15 April 2016; J.P. Arveiller and Clément Bonnet, $A u$ Travail, les activités productives dans le traitement et la vie du malade mental (Toulouse: ERES, 1991); Jennifer Laws, "Crackpots and Basket-cases: A History of Therapeutic Work and Occupation", History of the Human Sciences no. 24 (2011): 65-81; Geoffrey Reaume, "Patients at Work: Insane Asylum Inmates' Labour in Ontario, 1841-1900", in Mental Health in Canadian Society: Historical Perspectives, eds James Moran and David Wright (Montreal: McGill Queen's University Press, 2006), 69-116; Jean-Pierre Goubert and Rémi Remondière, "Les Origines Historiques de l'Ergothérapie en France", Revue Sociologique Santéno. 20 (2004): 247-68. 
3. Ministère de l'Intérieur, Bulletin Officiel sur le règlement intérieur des asiles d'aliénés, Circulaire No. 7, 20/03/1857, 57. www.gallica.bnf.fr. Accessed 13 March 2019.

4. Ian Dowbiggin, "Degeneration and Hereditarianism in French Mental Medicine 1840-90: Psychiatric Theory as Ideological Adaptation", in The Anatomy of Madness: Essays in the History of Psychiatry, ed. W.F. Bynum, Roy Porter and Michael Shepherd (London and New York: Tavistock Publications, 1985), 188-232, 210.

5. Ernst Abel, "Bénédict-Augustin Morel (1809-73)", in American Journal of Psychiatry 161, no. 12 (2004): 2185.

6. Jari Eloranta and Mark Harrison, "War and Disintegration, 1914-1950", in The Cambridge Economic History of Modern Europe, eds Stephen Broadberry and Kevin O'Rourke (Cambridge: Cambridge University Press, 2010), 133-55, 149.

7. Pierre-Cyril Hautcoeur, "Was the Great War a Watershed? The Economics of World War I in France", in The Economics of World War I, eds Stephen Broadberry and Mark Harrison (Cambridge: Cambridge University Press, 2005), 169-205, 199.

8. Archives de Paris (hereafter ADP) D.10K3/27/20, Louis Dausset, Rapport Général au nom de la 3e Commission sur les propositions budgétaires pour le Service des Aliénés (Paris: Conseil Général de la Seine, 1918), 27.

9. Ibid.

10. Ibid., 28.

11. Ibid., 43.

12. After serving on several professional commissions of the Superior Council of Public Hygiene, Raynier was appointed inspector general of administrative services for the Ministry of the Interior in 1935.

13. Beaudouin, a respected clinician, was Chief Medical Officer of the Maison Blanche asylum, 1926-55.

14. The importance of the work in the Raynier and Beaudouin volume has been highlighted by Michel Bénézech. See: Michel Bénézech, 2013. "Une Bible Oubliée de la pratique psychiatrie asilaire: Le Traité des docteurs Raynier et Beaudouin", in Annales Médico-psychologiques 171 no. 1 (2013): 51-3.

15. J. Raynier and H. Beaudouin, L'Aliéné et les Asiles d'Aliénés au point de vue administratif et juridique, assistance et législation (Paris: Librairie Le François, 1924), 313.

16. Ibid., 314.

17. Director of the Bel-Air Asylum in Geneva.

18. Chief Medical Officer of the Clermont Asylum in Clermont Ferrand, Oise.

19. C. Ladame and G. Demay, La thérapeutique des maladies mentales par le travail (Paris: Masson, 1926). 
20. Ibid., 22.

21. Ibid.

22. Defined as a temporary or permanent loss of brain function causing incoherence that could affect people of all ages. See: Edward Shorter, $A$ Historical Dictionary of Psychiatry (Oxford: Oxford University Press, 2005), 71-6.

23. Dementia praecox (démence précose) was first identified in 1860 by Morel as a form of hereditary dementia affecting teenagers; its classification was further developed by Emil Kraepelin in 1893. In 1908 it was then reclassified by Eugen Bleuler as schizophrenia, to include milder and broader categories. See: Shorter, Historical Dictionary of Psychiatry, 267-75.

24. Ladame and Demay, La thérapeutique, 24.

25. Ibid., 7 .

26. Ibid.

27. The disciplinary and therapeutic aims of work for patients in the Third Section are the subject of research by Véronique Fau-Vincenti. See footnote (2) above.

28. Henri Colin, "Le Quartier de Sureté de Villejuif (Aliénés criminels, vicieux, difficiles, habitués des asiles)", Annales Médico-psycholoique (novembre 1912): 370-91, (décembre 1912): 540-8; (janvier 1913): 36-65, (février 1913): 170-7.

29. Colin, "Le Quartier de Sureté", Annales Médico-psychologique (février 1913): 171-2.

30. Delirium is defined as acute brain failure resulting in reduced awareness of the environment such as loss of orientation, confusion, hallucinations and irrational fears; chronic delirium refers to the condition when it has become entrenched. See: Shorter, Historical Dictionary of Psychiatry, 70-1.

31. M. Calmels, "Le Travail par petits ateliers à la troisième section de l'Asile de Villejuif”, Annales Médico-psychologique (janvier 1927): 283.

32. Ibid., 283.

33. Dr Lautier, "Les Exagérations de la Thérapie par le Travail”, L’Hygiène Mentale no. 2 (1929): 191.

34. G. Demay, "Les conditions de la thérapeutique par le travail dans les asiles”, L’Hygiène Mentale no. 2 (1929): 33.

35. Ibid.

36. Ibid., 34.

37. Ibid.

38. Hermann Simon, "Active Therapy in the Lunatic Facility (1929)", in From Madness to Mental Health: Psychiatric Disorder and Its Treatment in Western Civilisation, ed. Greg Eghigian (New Brunswick: Rutgers University Press, 2010), 271-5, 272.

39. Ibid., 273. 
40. Ibid.

41. P. Schiff, “Le movement d'hygiène mentale an Allemagne", L'Hygiène Mentale no. 8 (1929): 232-3.

42. Jacques Postel and Claude Quetel, Nouvelle Histoire de la Psychiatrie (Paris: Dunod, 2012), 350.

43. George Weisz, "Reform and Conflict in French Medical Education, 1870-1914", in The Organisation of Science and Technology in France 1808-1914, eds Robert Fox and George Weisz (Cambridge: Cambridge University Press, 1980), 61-94, 64-5.

44. Jan Goldstein, Console and Classify: The French Psychiatric Profession in the Nineteenth Century (Chicago and London: University of Chicago Press, 2001), 350; Paul Lerner, Hysterical Men: War, Psychiatry and the Politics of Trauma in Germany, 1890-1930 (Ithaca, NY: Cornell University Press, 2003), 16.

45. Ibid.

46. Paul Courbon, "Un Voyage d'études dans les asiles en Hollande”, Annales Médico-psychologique (février 1928): 289-306 and 385-405, 396.

47. Ibid., 397; A. Porot, "L'Assistance par le travail dans les asiles Hollandais", L'Hygiène Mentale no. 2 (1929) 41-54, 52.

48. Porot, "L'Assistance par le travail", 52.

49. Ibid.

50. Hermann Simon, "La Psychothérapie à l'Asile”, L’Hygiène Mentale no. I (1933): 16-28, 21.

51. Ibid., 22.

52. Ibid.

53. Ibid., 23-5.

54. Ibid., 26.

55. Ibid.

56. Ibid., 27.

57. Ibid., 20.

58. Simon, "Active Therapy in the Lunatic Facility (1929)", 273.

59. These figures were gleaned from the Asile Clinique asylum directors' reports to the Paris prefecture 1921-39.

60. These figures were gleaned from the Asile de la Sarthe directors' reports to the Le Mans prefecture 1919-39.

61. Malaria therapy was introduced into French asylums between 1924 and 1932 , but this was only for patients suffering from general paralysis of the insane (GPI), a condition associated with tertiary syphilis.

62. ADP/D.10K3/27/20, Dausset, Rapport Général, 1918, 26.

63. Porot, "L'assistance par le travail”, 52.

64. Jean-Christophe Coffin, "“Misery and Revolution”: The Organisation of French Psychiatry, 1900-1980", in Psychiatric Cultures Compared: 
Psychiatry and Mental Health Care in the Twentieth Century, Comparisons and Approaches, eds M. Gijswijt-Hofstra, H. Oosterhuis and J. Vijselaar (Amsterdam: Amsterdam University Press, 2005), 225-48, 227.

65. Harry W. Paul, From Knowledge to Power: The Rise of the Science Empire in France 1860-1939 (Cambridge: Cambridge University Press, 1985), 2, 340.

66. Archives De La Sarthe (hereafter ADS) 1X964/5, Rapport du Médecin en Chef de l'Asile de la Sarthe (Le Mans: Préfecture de la Sarthe, 1935), 7.

67. Ibid.

68. ADS 1X964/5, Rapport du Médecin en Chef, 1937, 12.

69. Ibid.

70. J. Vié, “Le traitement des malades mentaux par le travail”, L'Aliéniste français (janvier 1934): 589-98, 597.

71. Ibid., 596.

72. D.-M. Legrain et G. Demay, "Le Travail des Aliénés Convalescents", L'Aliéniste français (décembre 1936), 281-97, 283.

73. Ibid.

74. Courbon, “Un voyage d'études”, 403; Porot, “L'Assistance par le travail", 50-1.

75. G. Demay, "Les conditions de la thérapeutique par le travail dans les asiles", L'Hygiène Mentale no. 2 (1929): 40.

76. Between 1924 and 1925 the maintenance costs rose by 11 million Francs and were set to rise by another 6.3 million in 1926 .

77. ADP/D.10K3/38/83, Chausse, Rapport Général, 1925, 7.

78. ADP/D.10K3/38/75, François Latour, Rapport au nom de la 6e Commission sur les comptes du directeur de l'Asile Clinique en 1924 (Paris: Conseil Général de la Seine, 1925), 20-1.

79. ADP/D1X3-44/6, Procès Verbal de la Visite de la Commission, 21-4 Avril 1923 (Paris: Commission de Surveillance des Asiles Publiques d'Aliénés de la Seine, 1923), 122.

80. By profits is meant the value of the produce (evaluated according to local market rates) minus the associated costs, including the wages of employees, such as the head gardener or bakery manager, the nominal amount paid to the working patients, raw materials such as seeds or flour, and other costs such as equipment, fertiliser, fencing etc.

81. ADS-1X964/5, Rapport du Directeur de l'Asile de la Sarthe (Le Mans: Préfecture de la Sarthe, 1920), [no page numbers].

82. Demay, "Les conditions", 37.

83. Ibid.

84. Legrain and Demay, "Le travail des aliénés convalescents", 283.

85. Ibid.

86. E. Jean-Louis and A. Valentine, "Un institut au coeur de l'histoire de la profession infirmière", in L'Hôpital Sainte-Anne, Pionnier de la Psychiatrie 
et des neurosciences au coeur de Paris, eds S. Henry, C. Lavielle and

F. Patenotte (Paris: Somogy Éditions d'Art, 2016), 170-1.

87. Courbon, "Un Voyage d'étude", 399.

88. Ibid.

89. Patrice Krzyzaniak, “Georges Daumézon (1912-1979): Un Camisard Psychiatre Et Pédagogue: Une Contribution Singuliere Aux Sciences De L'éducation" (Paris: Université Charles de Gaulles, 2018), 89.

90. ADS-1X964/5, Rapport du Directeur, 1920, 16.

91. ADS-1X261, Rapport du Médecin en Chef, 1933 [no page numbers].

92. Ibid.

93. ADS-1X964/5, Rapport du Médecin en Chef, 1937, 13.

94. Ibid.

95. ADS-1X261, Rapport du Médecin en Chef, 1933 [no page numbers].

96. ADS-1X964/5, Rapport du Médecin en Chef, 1937, 22.

Open Access This chapter is licensed under the terms of the Creative Commons Attribution 4.0 International License (http://creativecommons.org/licenses/ by $/ 4.0 /)$, which permits use, sharing, adaptation, distribution and reproduction in any medium or format, as long as you give appropriate credit to the original author(s) and the source, provide a link to the Creative Commons licence and indicate if changes were made.

The images or other third party material in this chapter are included in the chapter's Creative Commons licence, unless indicated otherwise in a credit line to the material. If material is not included in the chapter's Creative Commons licence and your intended use is not permitted by statutory regulation or exceeds the permitted use, you will need to obtain permission directly from the copyright holder.

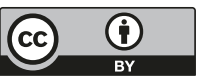

